\title{
KETERBUKAAN DIRI (SELF DISCLOSURE)PEREMPUAN KORBAN KEKERASAN DALAM RUMAH TANGGA SELAMA PANDEMI COVID-19 DI KELURAHAN REJOSARI KECAMATAN SEMARANG TIMUR KOTA SEMARANG
}

\author{
Sasdilla Fieren Agliesta Sutopo \\ Politeknik Kesejahteraan Sosial Bandung,fierensutopo@gmail.com \\ Nono Sutisna \\ Politeknik Kesejahteraan Sosial Bandung, nonostitin@gmail.com \\ Atirista Nainggolan \\ Politeknik Kesejahteraan Sosial Bandung, atiristanainggolan2019@gmail.com
}

\begin{abstract}
The Covid-19 pandemic period with various restrictions has made more people stay at home. This condition triggers new problems in the family including domestic violence. One of the vulnerable groups affected is women; meanwhile many women choose not to open themselves up to the violence they experience. Self-disclosure is a process of communication by which one person reveals information about themselve to another, which is usually hidden or confidential containing facts about the individual not known by others in the surrounding, can also be related to the situation faced and providing relevant information in the past or useful for understanding the current situation. As a result of this lack of self-disclosure, women experience a psychological burden and always get discriminatory behavior. The research aims to describe more about self-disclosure of women victims of domestic violence during Covid-19 pandemic in Rejosari Village, East SemarangSubdistrict,Semarang Regency. The research uses aqualitative approach with descriptive methods. The data collection uses an in depth interview, observation, and documentation study. The informants are determined by using purposive sampling to seven informants consisting of women victims of domestic violence, parents, health worker, and member of Integrated Service Center Seruni East Semarang Subdistrict.The result shows that self-disclosure of women victims of domestic violence during Covid-19 pandemic has been done well. After revealing self-disclosure there are problems that arise which are trauma feeling and anxiety towards domestic violence. Based on the research, the researcher proposes a program to socially assist towards the trauma feeling and anxiety of women victims of domestic violence during Covid-19 pandemic after revealing self-disclosure through Referral Service Agency Rumah Aman.The program aims to give a sense of security and reduce trauma and anxiety among women victims of domestic violence during Covid-19 pandemic after revealing self-disclosure.
\end{abstract}

Keywords:

Self Disclosure, Women Victims of Domestic Violence, Covid-19 Pandemic

\begin{abstract}
Abstrak
Masa pandemi Covid-19 dengan berbagai pembatasan membuat orang lebih banyak tinggal di rumah. Kondisi tersebut memicu masalah baru didalam keluarga termasuk kekerasan dalam rumah tangga. Salah satu kelompok yang rentan terdampak adalah perempuan; sedangkan banyak perempuan memilih untuk tidak melakukan keterbukaan diri terhadap tindak kekerasan yang dialaminya. Keterbukaan diri adalah suatu bentuk penyampaian informasi tentang diri individu kepada orang lain yang biasanya disembunyikan atau dirahasiakan, memuat fakta
\end{abstract}


mengenai diri individu dan belum diketahui oleh orang lain yang berada dilingkungan sekitarnya, serta memberikan informasi tentang masa lalu individu yang relevan atau yang berguna untuk memahami situasi di masa kini. Akibat dari ketidakadanya keterbukaann diri tersebut perempuan mengalami beban psikologis dan selalu mendapatkan perilaku diskriminasi. Penelitian ini bertujuan untuk mengetahui gambaran lebih mendalam keterbukaan diri yang dilakukan oleh perempuan korban kekerasan dalam rumah tangga selama pandemi Covid-19 di Kelurahan Rejosari Kecamatan Semarang Timur Kota Semarang. Metode yang digunakan dalam penelitian ini adalah pendekatan kualitatif dengan metode deskripsitif. Teknik yang digunakan untuk pengumpulan data adalah wawancara mendalam, observasi dan studi dokumentasi. Penentuan informan dengan menggunakan purposive sampling berjumlah tujuh informan yang terdiri dari tiga perempuan korban kekerasan dalam rumah tangga, dua orang tua, satu tenaga kesehatan dan satu anggota Pusat Pelayanan Terpadu Seruni Kecamatan Semarang Timur. Hasil penelitian menunjukkan keterbukaan diri perempuan korban kekerasan dalam rumah tangga selama pandemi Covid-19 telah dilakukan dengan baik. Pasca melakukan keterbukaan diri terdapat permasalahan yang muncul yaitu rasa trauma dan rasa cemas terhadap tindak kekerasan dalam rumah tangga. Berdasarkan hasil penelitian tersebut, maka peneliti mengusulkan program pendampingan sosial terhadap rasa trauma dan rasa cemas perempuan korban kekerasan dalam rumah tangga selama pandemi Covid-19 pasca melakukan keterbukaan diri melalui Lembaga Layanan Rujukan Rumah Aman. Program ini bertujuan untuk memberikan rasa aman, mengurangi rasa trauma dan rasa cemas perempuan korban kekerasan dalam rumah tangga selama pandemi Covid-19 pasca melakukan keterbukaan diri.

Kata Kunci:

Keterbukaan Diri, Perempuan Korban Kekerasan Dalam Rumah Tangga, Pandemi Covid-19

\section{PENDAHULUAN}

Seluruh belahan dunia saat ini sedang mengalami fenomena pandemi Covid-19 atau dikenal dengan sebutan virus corona.Pandemi merupakan epidemi yang menyebar ke beberapa negara dan pada umumnya menjangkiti banyak orang. Pada tanggal 11 Maret 2020, World Health Organization (WHO) menetapkan Covid-19 sebagai pandemi. Merespon status pandemi global tersebut, pemerintah Indonesia mengeluarkan regulasi untuk melawan virus Covid-19 (dalam Portal Informasi Indonesia, 2020).Regulasi pemerintah tersebut adalah Undang-Undang Republik Indonesia Nomor 2 Tahun 2020 tentang Penetapan Peraturan Pemerintah Pengganti Undang-Undang Nomor 1 Tahun 2020 tentang Kebijakan Keuangan Negara dan Stabilitas Keuangan untuk Penanganan Pandemi Corona Virus
Disease 2019 (Covid-19) dan/atau Dalam Rangka Menghadapi Ancaman yang Membahayakan Perekonomian Nasional dan/atau Stabilitas Sistem Keuangan Menjadi Undang-Undang. Kemudian, kebijakan yang dikeluarkan tentang Pembatasan Sosial Berskala Besar (PSBB), tentang pembatasan berbagai kegiatan masyarakat yaitu peniadaan sekolah secara luring, bekerja di kantor dibagi menjadi Work From Office dan Work From Home, pembatasan kegiatan pada fasilitas umum, pembatasan kegiatan keagamaan, pembatasan kegiatan sosial budaya dan pembatasan transportasi umum. Gubernur Jawa Tengah juga telah mengeluarkan Keputusan Gubernur Jawa Tengah Nomor 360/3 Tahun 2020 tentang Tanggap Darurat Bencana Covid-19.Pandemi tersebut mengharuskan kita melakukanpemutusan rantai transmisi dan melindungi populasi dari 
resiko.Indonesia salah satu negara yang telah menghimbau adanya Pembatasan Sosial Berskala Besar (PSBB) sebagai upaya dari social distancing. Pembatasan Sosial Berskala Besar (PSBB) adalah suatu pembatasan kegiatan tertentu penduduk dalam suatu wilayah yang diduga terinfeksi virus Covid-19 guna mencegah penyebaran virus.

Resiko komplikasi dari pandemi Covid-19 menimbulkan dampak di masyarakat secara ekonomi, psikologis dan sosial. Faktor ekonomi menjadi pemicu utama pada saat pandemi Covid-19 karena pengeluaran tidak sebanding dengan pendapatan. Komnas Perempuan (2020) menyatakan bahwa dalam masa pandemi Covid-19 dengan berbagai pembatasan sehingga membuat orang lebih banyak tinggal di rumah menimbulkan berbagai masalah baru didalam keluarga termasuk kekerasan dalam rumah tangga. Menurut Undang-Undang Nomor 23 Tahun 2004 Kekerasan dalam Rumah Tangga merupakan setiap perbuatan terhadap seseorang terutama perempuan, yang berakibat timbulnya kesengsaraan atau penderitaan secara fisik, seksual, psikologis dan/atau penelantaran rumah tangga termasuk ancaman untuk melakukan perbuatan, pemaksaan atau perampasan kemerdekaan secara melawan hukum dalam lingkup rumah tangga. Salah satu kelompok yang sangat rentan terdampak adalah perempuan. Menurut Komnas Perempuan dengan diberlakukannya kebijakan Pembatasan Sosial Berskala Besar (PSBB) menjadikan rumah tempat tidak aman bagi perempuan. Hal ini dikarenakan perempuan akan mendapatkan beban domestik berlapis yang mengakibatkan perempuan menyembunyikan kasus kekerasan dalam rumah tangga yang dialaminya.

Devito (dalam Yosal Iriantara, 2017) menyatakan bahwa keterbukaan diri sebagai suatu bentuk komunikasi dimana informasi tentang diri kita yang biasanya disimpan atau disembunyikan, dikomunikasikan pada orang lain. Namun, banyak perempuan yang memilih untuk tidak melakukan keterbukaan diri terhadap tindak kekerasan yang dialaminya. Hal ini dikarenakan adanya pembatasan peran perempuan oleh struktur sosial patriarki dan lemahnya perlindungan hukum menempatkan perempuan menjadi termajinalisasikan. Tindak kekerasan dalam rumah tangga akan menimbulkan beban psikologis terhadap para korban. Mereka akan rentan mengalami trauma, depresi dan kecemasan. Sedangkan, keterbukaan diri penting untuk dilakukan oleh korban kekerasan agar para pendamping lebih memahami kondisi yang dialaminya sehingga memudahkan proses pendampingan dalam pemulihan kondisi psikologis korban kekerasan.

Catatan Tahunan (CATAHU) Komnas Perempuan mencatat bahwa selama masa pandemi Covid-19 pada bulan Januari-Juni tahun 2020 ini Kekerasan Dalam Rumah Tangga masih menempati urutan pertama yang dimana peningkatan $75,4 \%$ dengan jumlah 14.719 kasus. Kemudian, Dinas Perempuan Perlindungan Anak Pengendalian Penduduk dan Keluarga Berencana (DP3AP2KB) Jawa Tengah menyatakan terjadi 659 kasus kekerasan. Sedangkan, kasus kekerasan di Kota Semarang terdapat 76 kasus kekerasan. Selanjutnya, wilayah Kecamatan Semarang Timur Kota Semarang mencatat bahwa ditemukan kasus kekerasan dalam rumah tangga berjumlah14 kasus kekerasan yang didominasi oleh Kelurahan Rejosari dengan 5 kasus kekerasan.Dinas Pemberdayaan 
Perempuan dan Perlindungan Anak Kota Semarang menyatakan bahwa masyarakat Kelurahan Rejosariyang sebagian besar bekerja sebagai buruh mengalami penurunan penghasilan selama pandemi Covid-19 bahkan terkena Pemutusan Hubungan Kerja (PHK), sehingga situasi tersebut menambah beban pikiran masyarakat dan mengakibatkanterjadinya tindak kriminalitas termasuk kekerasan dalam rumah tangga.

Perempuan korban kekerasan dalam rumah tangga dan telah melakukan keterbukaan diri terkait dengan kasus yang dialami di Kelurahan Rejosari Kecamatan Semarang Timur Kota Semarang menjadi fokus yang dapat dijadikan sebagai objek penelitian. Hal ini dikarenakan pengalaman kehidupan yang dialami setelah melakukan keterbukaan diri menjadi peristiwa yang menarik. Disamping hal tersebut, masih ada kemungkinan resiko yang terjadi seperti penolakan pribadi dan sosial serta beban yang ditimbulkan setelah melakukan keterbukaan diri.

Berdasarkan uraian diatas, peneliti tertarik untuk melakukan penelitian mengenai "Keterbukaan Diri Perempuan Korban Kekerasan Dalam Rumah Tangga Selama Pandemi Covid-19 di Kelurahan Rejosari Kecamatan Semarang Timur Kota Semarang”. Aspek yang akan diteliti adalah ukuran/jumlah, valensi/kualitas, kejujuran dan kecermatan, maksud dan tujuan serta keakraban keterbukaan diri. Tujuan dari penelitian ini adalah untuk mengetahui karakteristik perempuan korban kekerasan dalam rumah tangga, ukuran/jumlah keterbukaan diri perempuan korban kekerasan dalam rumah tangga, valensi/kualitas keterbukaan diri perempuan korban kekerasan dalam rumah tangga, kecermatan dan kejujuran keterbukaan diri perempuan korban kekerasan dalam rumah tangga, maksud dan tujuan keterbukaan diri perempuan korban kekerasan dalam rumah tangga serta keakraban keterbukaan diri perempuan korban kekerasan dalam rumah tangga.

\section{METODE}

Desain penelitian yang digunakan dalam penelitian ini adalah deskriptif kualitatif untuk menjelaskan dan memahami secara mendalam keterbukaan diri perempuan korban kekerasan dalam rumah tangga selama pandemi Covid-19 di Kelurahan Rejosari Kecamatan Semarang Timur Kota Semarang. Cara menentukan sumber data primer ditentukan melalui teknik purposive sampling. Sumber data primer dalam penelitian ini adalah tiga perempuan korban kekerasan dalam rumah tangga, dua orang tua, satu tenaga kesehatan dan satu anggota Pusat Pelayanan Terpadu (PPT) Seruni Kecamatan Semarang Timur. Sedangkan, sumber data sekunder diperoleh dari profil Kelurahan Rejosari dan data korban kekerasan dalam rumah tangga Dinas Pemberdayaan Perempuan dan Perlindungan Anak Kota Semarang. Teknik pengumpulan data menggunakan wawancara mendalam, observasi dan studi dokumentasi. Kemudian, pemeriksaan keabsahan data menurut Moleong (2017) dengan perpanjangan keikutsertaan, ketekunan/keajegan pengamatan dan triangulasi data.

\section{HASIL PENELITIAN}

Hasil penelitian mengenai keterbukaan diri perempuan korban kekerasan dalam rumah tangga selama pandemi Covid-19 di Kelurahan Rejosari Kecamatan Semarang Timur Kota Semarang sebagai berikut. 
1. Karaktersitik Perempuan Korban Kekerasan Dalam Rumah Tangga

Tabel 1 Karakteristik Perempuan Korban Kekerasan Dalam Rumah Tangga

\begin{tabular}{|l|l|l|l|}
\hline Nama & Usia & $\begin{array}{l}\text { Status } \\
\text { Pernikahan }\end{array}$ & \multicolumn{1}{|c|}{ Pekerjaan } \\
\hline S & 36 & Bercerai & Buruh \\
\hline RN & 19 & $\begin{array}{l}\text { Proses } \\
\text { Bercerai }\end{array}$ & Pedagang \\
\hline I & 22 & Menikah & $\begin{array}{l}\text { Ibu Rumah } \\
\text { Tangga }\end{array}$ \\
\multicolumn{2}{|c|}{ Informan } & \multicolumn{2}{|c|}{ perempuan korban }
\end{tabular}

kekerasan dalam rumah tangga selama pandemi Covid-19 berusia 19 hingga 36 tahun. Mereka menikah muda pada usia 16 tahun akibat hamil diluar nikah. Status pernikahannya adalah bercerai dan menikah. Pendidikan terakhir dua perempuan SMP dan satu perempuan SMK. Mereka bekerja sebagai buruh, pedagang dan ibu rumah tangga.

\section{Ukuran/Jumlah Keterbukaan Diri}

Hasil penelitian dari aspek ukuran/jumlah keterbukaan diridengan melakukan triangulasi sumber membuktikan bahwa ketiga perempuan korban kekerasan telah menyampaikan informasi diri terkait dengan kekerasan dalam rumah tangga secara konsisten. Mereka menyampaikan pesan keterbukaan diri selama 10 hingga 30 menit. Mereka mengungkapkan permasalahan kekerasan dalam rumah tangga tidak sering namun, hanya kepada significant others yang dipercayainya. Topik pembicaraan yang disampaikan tidak banyak dan langsung pada inti pembicaraan.

Hasil triangulasi waktu yang dilakukan pada hari yang berbeda dengan jarak waktu kurang lebih 1 minggu menyatakan bahwa semua jawaban Informan konsisten. Mereka melakukan keterbukaan diri terkait dengan kekerasan dalam rumah tangga yang dialaminya dimomen penting saja seperti ketika perempuan korban kekerasan ingin melaporkan suaminya atas kasus kekerasan dalam rumah tangga. Cara mereka melakukan keterbukaan diri adalah dengan komunikasi langsung dengan orang yang dipercayai dan menjawab pertanyaan yang dilontarkan oleh orang lain.

\section{Valensi/Kualitas Keterbukaan Diri}

Hasil penelitian dari aspek valensi atau kualitas keterbukaan diri adalah informasi yang diberikan oleh ketiga perempuan korban kekerasan dengan significant others relevan. Informan $\mathrm{S}$ mengungkapkan permasalahan yang dialami kepada anggota PPT Seruni Kecamatan Semarang Timur dengan ungkapan negatif yaitu menangis dan sedih. Kemudian, Informan $\mathrm{RN}$ mengungkapkan permasalahan yang dialami dengan orang tua dan anggota PPT Seruni Kecamatan Semarang Timur dengan ungkapan negatif menangis kepada orang tua dan ungkapan yang positif tenang kepada anggota PPT Seruni Kecamatan Semarang Timur. Sedangkan Informan I melakukan keterbukaan diri dengan ungkapan yang negatif menangis kepada tenaga kesehatan dan orang tua.

Respon yang didapatkan oleh Informan S adalah respon positif berupa dukungan dari anggota PPT Seruni Kecamatan Semarang Timur dan respon negatif berupa penolakan untuk membantu menyelesaikan permasalahan korban. Kemudian, respon yang didapatkan oleh Informan RN adalah respon positif berupa dukungan untuk melaporkan pelaku dari anggota PPT Seruni Kecamtan Semarang Timur dan orang tua. Sedangkan, respon yang didapatkan oleh Informan I adalah respon positif berupa dukungan dari tenaga kesehatan Kecamatan Semarang Timur dan respon 
negatif berupa menangis dan marah dari orang tua.

Hasil dari triangulasi waktu ini adalah ketiga perempuan korban kekerasan konsisten dalam menjawab pertanyaan dari peneliti bahwa mereka melakukan pengungkapan kalimat yang mengandung makna keterbukaan diri disampaikan kepada orang tua dan anggota PPT Seruni Kota Semarang mengenai rasa trauma akibat kekerasan dalam rumah tangga yang dialami.

\section{Kecermatan dan Kejujuran Keterbukaan Diri}

Hasil penelitian dari aspek kecermatan dan kejujuran adalah informasi yang diberikan oleh ketiga perempuan korban kekerasan dengan significant others relevan. Kecermatan pada aspek keterbukaan diri dapat dilihat dari cara salah satu Informan I dalam menentukan kalimat yang tepat untuk melakukan keterbukaan diri kepada orang tuanya agar tidak memberikan beban pikiran. Kemudian, dalam menentukan waktu ketiga Informan cukup tepat dalam melakukan keterbukaan diri. Peneliti melakukan cross check jawaban dengansignificant others yang dapat disimpulkan bahwa Informan S, Informan $\mathrm{RN}$ dan Informan I melakukan keterbukaan diri setelah mendapatkan kekerasan dari suaminya. Sehingga luka fisik masih terlihat dan dapat dijadikan sebagai bukti.

Pengaruh paling besar pasca melakukan keterbukaan diri adalah trauma dan cemas. Ketiga perempuan korban kekerasan dan significant others mengungkapkan pengaruh tersebut muncul mengakibatkan perempuan korban kekerasan selalu merasa waspada terhadap orang lain, tidak tenang dalam menjalani kehidupan sehari-hari, tidak bisa tidur nyenyak dan takut apabila bertemu dengan laki-laki. Significant others mengkonfirmasi bahwa informasi yang diberikan perempuan korban kekerasan adalah benar adanya.

Hasil triangulasi waktu menyatakan bahwa kejujuran dilihat dari konsistensi perempuan korban kekerasan dalam menjawab pertanyaan peneliti walaupun dilain hari. Triangulasi teknik dilakukan oleh peneliti melalui wawancara mendalam, observasi secara langsung dan studi dokumentasi. Hasilnya adalah ketiga teknik tersebut dilakukan secara serentak. Wawancara mendalam terhadap perempuan korban kekerasan menyebutkan bahwa mereka mengalami trauma dan kecemasan apabila bertemu dengan orang lain yang tidak ia kenali. Mereka pada awalnya tidak ingin melaporkan karena mereka tidak mengetahui kekerasan dalam rumah tangga merupakan tindakan pidana. Ketika peneliti melakukan observasi secara langsung kepada perempuan korban kekerasan, ketika menjawab pertanyaan menangis, terbata-bata ketika menjelaskan dan mata selalu menatap ke bawah. Kemudian, peneliti juga mengamati bahwa pada awalnya mereka enggan untuk melakukan pertemuan dengan peneliti. Hal ini dikarenakan perempuan korban kekerasan mengalami ketakutan yang tinggi apabila bertemu dengan orang baru, mereka takut apabila orang tersebut adalah orang yang selalu melakukan teror. Selanjutnya, studi dokumentasi dilakukan dengan mempelajari kajian teori yang menyatakan bahwa akibat dari kekerasan dalam rumah tangga akan menimbulkan trauma pada korban.

\section{Maksud dan Tujuan Keterbukaan Diri}

Hasil penelitian dari aspek maksud dan tujuan adalah informasi yang diberikan oleh 
ketiga perempuan korban kekerasan dengan significant others relevan. Mereka melakukan keterbukaan diri dengan tujuan agar mendapatkan perlindungan dan keadilan. Hambatan yang dirasakan adalah mereka takut terhadap ancaman suami karena hidup didalam pengawasannya. Siginificant others juga mengungkapkan demikian ditambah Informan I memiliki rasa ketergantungan secara ekonomi terhadap pelaku. Untuk mengatasi hambatan tersebut mereka memberanikan diri untuk pulang ke rumah orang tuanya guna meminta bantuan.

\section{Keakraban}

Hasil penelitian dari aspek keakraban dengan triangulasi sumber peneliti terhadap orang tua, tenaga kesehatan dan anggota PPT Seruni Kecamatan Semarang menyebutkan bahwa ketiga perempuan korban kekerasan melakukan keterbukaan diri dengan jawaban yang sama. Hal ini dibuktikan dengan Informan S dan Informan RN mengungkapkan hal pribadi tentang kekerasan yang diterima. Kemudian, Informan I menyampaikan hal-hal pribadi tentang kepribadian suaminya. Namun, significant others menyatakan suami dari ketiga perempuan korban kekerasan sering mengonsumsi narkoba, mabuk dan tidak menafkahi dengan layak. Mereka juga mengungkapkan orang yang paling mereka percayai untuk bercerita masalah yang dialaminya adalah Ibu Z anggota PPT Seruni Kecamatan Semarang. Tempat mereka mengungkapkan diri adalah di rumah orang tua, kantor PPT Seruni dan depan mushola. Hal ini mengartikan bahwa keterbukaan diri tidak dilakukan ditempat tinggal bersama pelaku kekerasan. Hasil triangulasi waktu semua perempuan korban kekerasan dan significant others konsisten menjawab pertanyaan dari peneliti.
Triangulasi teknik dilakukan oleh peneliti dengan wawancara mendalam telah menunjukkan keterbukaan diri perempuan korban kekerasan. Kemudian, peneliti melakukan observasi secara langsung ketika perempuan korban kekerasan sedang berbincang dan bercerita dengan significant others. Peneliti mengamati Informan $\mathrm{S}$ dengan Informan Ibu Z memiliki kedekatan dan saling bercerita. Selanjutnya, Informan RN dengan Informan Ibu RN dan Informan Ibu Z seperti tidak ada batasan jarak antar satu sama lain. Peneliti juga mengamati hubungan Informan I dengan Informan Ibu I sangat dekat. Studi dokumentasi juga dilakukan pada aspek ini dengan mempelajari kajian literatur mengenai penyebab kekerasan dalam rumah tangga.

Berikut ini merupakan tabel rekapitulasi hasil penelitian keterbukaan diri perempuan korban kekerasan dalam rumah tangga selama pandemi Covid-19 di Kelurahan Rejosari Kecamatan Semarang Timur Kota Semarang. 

Tabel 2 Rekapitulasi Hasil Penelitian

\begin{tabular}{|c|c|c|c|}
\hline No & Aspek & Sub Aspek & Kategorisasi \\
\hline 1. & Ukuran/Jumlah & $\begin{array}{l}\text { a. Sasaran } \\
\text { b. Topik yang Diceritakan } \\
\text { c. Waktu yang Tepat } \\
\text { d. Frekuensi } \\
\text { e. Durasi } \\
\text { f. Cara Melakukan } \\
\text { Keterbukaan Diri }\end{array}$ & $\begin{array}{l}\text { a. Ketiga perempuan korban menceritakan } \\
\text { kasus kekerasan kepada orang tua, tenaga } \\
\text { kesehatan, anggota PPT Seruni dan teman } \\
\text { dekat } \\
\text { b. Durasi yang dibutuhkan 10-30 menit } \\
\text { c. Cara melakukan keterbukaan diri dengan } \\
\text { bercerita dan menjawab pertanyaan. }\end{array}$ \\
\hline 2. & Valensi/Kualitas & $\begin{array}{l}\text { a. Ungkapan Keterbukaan } \\
\text { Diri Positif atau Negatif } \\
\text { b. Alasan Melakukan } \\
\text { Keterbukaan Diri } \\
\text { c. Respon yang Diterima }\end{array}$ & $\begin{array}{l}\text { a. Ketiga Informan mengungkapkan } \\
\text { keterbukaan diri dengan ungkapan } \\
\text { negatif yaitu menangis dan sedih. } \\
\text { b. Alasan ketiga perempuan korban } \\
\text { mengungkapkan keterbukaan diri karena } \\
\text { takut, terancam dan sudah tidak kuat } \\
\text { menahan rasa sakit. } \\
\text { c. Respon yang diterima adalah positif } \\
\text { berupa dukungan dan negatif berupa } \\
\text { penolakan. }\end{array}$ \\
\hline 3. & $\begin{array}{l}\text { Kecermatan dan } \\
\text { Kejujuran }\end{array}$ & $\begin{array}{l}\text { a. Topik Sebelum Bercerita } \\
\text { Keterbukaan Diri } \\
\text { b. Cara Penentuan Kalimat } \\
\text { c. Pengaruh Paling Besar } \\
\text { d. Kebenaran Informasi }\end{array}$ & $\begin{array}{l}\text { a. Ketiga perempuan korban bercerita } \\
\text { tanpa basa-basi/small talk } \\
\text { b. Cara mengungkapkan keterbukaan diri } \\
\text { satu perempuan korban menentukan } \\
\text { kalimat dan dua perempuan korban tanpa } \\
\text { menentukan kalimat. } \\
\text { c. Pengaruh pasca melakukan keterbukaan } \\
\text { diri adalah takut, trauma dan cemas. }\end{array}$ \\
\hline 4. & $\begin{array}{l}\text { Maksud } \\
\text { Tujuan }\end{array}$ & $\begin{array}{l}\text { a. Tujuan } \\
\text { b. Hambatan } \\
\text { c. Cara Mengatasi } \\
\text { Hambatan }\end{array}$ & $\begin{array}{l}\text { a. Tujuan melakukan keterbukaan diri } \\
\text { adalah untuk mendapatkan perlindungan } \\
\text { dan keadilan. } \\
\text { b. Hambatan yang dihadapi adalah } \\
\text { perempuan korban kekerasan berada } \\
\text { pada pengawasan pelaku yaitu } \\
\text { suaminya. } \\
\text { c. Cara mengatasinya dengan } \\
\text { memberanikan diri untuk meminta } \\
\text { bantuan. }\end{array}$ \\
\hline 5. & Keakraban & $\begin{array}{l}\text { a. Hal-Hal Pribadi yang } \\
\text { Disampaikan } \\
\text { b. Orang yang Paling } \\
\text { Dipercaya } \\
\text { c. Tempat Menceritakan } \\
\text { Hal Pribadi } \\
\text { d. Cara Membangun } \\
\text { Komunikasi }\end{array}$ & $\begin{array}{l}\text { a. Hal pribadi yang disampaikan terkait } \\
\text { dengan kepribadian suaminya dan } \\
\text { kekerasan yang dialami. } \\
\text { b. Orang yang paling dipercaya ketiga } \\
\text { perempuan korban kekerasan adalah } \\
\text { anggota PPT Seruni } \\
\text { c. Tempat melakukan keterbukaan diri di } \\
\text { rumah orang tua, kantor PPT Seruni dan } \\
\text { depan Mushola }\end{array}$ \\
\hline
\end{tabular}

Sumber: Penelitian Mahasiswa Poltekesos Bandung Tahun 2021 


\section{PEMBAHASAN}

Devito (dalam Yosal Iriantara, 2017) menyebutkan bahwa terdapat lima dimensi keterbukaan diri yaitu ukuran/jumlah, valensi/kualitas, kecermatan dan kejujuran, maksud dan tujuan serta keakraban keterbukaan diri. Devito (dalam Yosal Iriantara, 2017) menyatakan bahwa keterbukaan diri sebagai suatu bentuk komunikasi dimana informasi tentang diri kita yang biasanya disimpan atau disembunyikan, dikomunikasikan pada orang lain. Keterbukaan diri pada perempuan korban kekerasan dalam rumah tangga selama pandemi Covid-19 mengungkapkan atau menyatakan diri terhadap lawan komunikasi. Berikut analisis terhadap penelitian yang telah dilakukan.

\section{Karakteristik Perempuan Korban} Kekerasan dalam Rumah Tangga

Perempuan korban kekerasan dalam rumah tangga di Kelurahan Rejosari berusia 19-36 tahun. Mereka menikah pada usia 16 tahun yang disebabkan oleh hamil diluar nikah. Didalam Undang-Undang Nomor 16 Tahun 2019 tentang Perubahan atas Undang-Undang Nomor 1 Tahun 1974 tentang Perkawinan menyatakan bahwa usia pernikahan untuk perempuan adalah 19 tahun dan laki-laki 21 tahun.

Sanderwitz dan Paxman (1994) berpendapat bahwa pernikahan muda sering terjadi karena seseorang berpikir secara emosional untuk melakukan pernikahan. Sedangkan, hidup berumah tangga membutuhkan kematangan emosi dan pemikiran untuk menghadapi serta mengendalikan hakekat perkawinan dan peran orang tua yang akan disandang. Ketidaksiapan keluarga muda ini mengakibatkan mereka masih sulit mengontrol emosi sehingga terjadinya kekerasan dalam rumah tangga, perceraian dan hubungan tidak baik dengan mertua.

\section{Ukuran/Jumlah Keterbukaan Diri}

Ukuran/jumlah keterbukaan diri berkaitan dengan seberapa banyak jumlah informasi diri kita yang diungkapkan. Jumlah tersebut bisa dilihat berdasarkan frekuensi kita menyampaikan pesan-pesan keterbukaan diri atau bisa dengan menggunakan ukuran waktu, yakni berapa lama kita menyampaikan pesanpesan yang mengandung keterbukaan diri pada keselurahan kegiatan komunikasi dengan lawan komunikasi. Ketiga Informan secara langsung mengungkapkan diri kepada orang yang dipercayai, mereka adalah orang tua, tenaga kesehatan, anggota PPT Seruni dan teman dekat.

Frekuensi perempuan korban kekerasan dalam rumah tangga selama pandemi Covid-19 dalam melakukan keterbukaan diri adalah tidak sering. Hal tersebut disebabkan oleh perempuan cukup selektif dalam mengungkapkan hal pribadinya kepada orang lain. Menurut Devito (dalam Yosal Iriantara, 2017) menyatakan bahwa tidak seluruh informasi yang sifatnya pribadi perlu disampaikan ke orang lain. Durasi yang dibutuhkan yaitu 10 menit hingga dengan 30 menit. Hal ini dikarenakan topik pembicaraan langsung pada inti pembicaraan.

\section{Valensi/Kualitas Keterbukaan Diri}

Valensi keterbukaan diri berkaitan dengan kualitas keterbukaan diri seseorang positif atau negatif saat seseorang menyampaikan siapa dirinya. Menurut Devito (2011) menyatakan bahwa ungkapan positif berarti disampaikan dengan menyenangkan, penuh humor dan menarik, sedangkan ungkapan negatif disampaikan dengan caramarah, kecewa, sedih dan menangis. Ketiga perempuan korban kekerasan dalam 
rumah tangga melakukan keterbukaan diri dengan ungkapan positif dan ungkapan negatif.

Cara mereka menyampaikan dengan bercerita secara langsung dengan orang yang dipercaya dan menjawab pertanyaan dari lawan bicaranya. Menurut Griffin (dalam Yosal Iriantara, 2017) dalam prosesnya keterbukaan diri bersifat timbal balik artinya keterbukaan diri akan diimbangi juga oleh keterbukaan diri lawan komunikasi atau sebaliknya. Berdasarkan pandangan ini, keterbukaan diri tidak dapat berlangsung apabila salah satu pihak yang terlibat dalam komunikasi menunjukkan ketertutupan dirinya.

Alasan perempuan korban kekerasan dalam rumah tangga menyampaikan ungkapan baik secara positif maupun negatif adalah mereka takut dan cemas atas ancaman serta terror yang dilakukan oleh pelaku.

Hasil penelitian Rifka Anissa Women's Crisis Centre (dalam Moerti Hadiati Soeroso, 2012) menyatakan bahwa karakteristik perempuan korban kekerasan dalam rumah tangga antara lain merasa bersalah, menyangkut terror dan kemarahan yang dirasakan, berwajah tidak berdaya tetapi sangat kuat menyembunyikan keadaan yang sebenarnya dan yakin bahwa tidak ada orang lain yang mampu menolong penderitaannya. Karakteristik tersebut yang dimiliki perempuan korban kekerasan dalam rumah tangga sebelum memutuskan melakukan keterbukaan diri. Sehingga ketiganya melakukan ungkapan negatif dengan menangis merupakan cara mereka meluapkan emosi yang selama ini telah dipendamnya.

Respon yang didapatkan ketika korban melakukan keterbukaan diri adalah respon negatif dari orang tuanya berupa penolakan, tidak mendukung proses hukum yang akan diajukan oleh korban dan marah. Respon negatif berupa penolakan tersebut didapatkan oleh salah satu perempuan korban kekerasan karena tidak memiliki kedekatan dengan orang tuanya. Seseorang tidak bisa mengharapkan respon yang selalu positif terhadap orang lain yang perlu lakukan adalah menyiapkan segala ungkapan yang diberikan.

\section{Kecermatan dan Kejujuran Keterbukaan Diri}

Kecermatan menurut Devito (dalam Yosal Iriantara, 2017) dalam keterbukaan diri yang seseorang lakukan akan sangat ditentukan oleh kemampuan seseorang dalam mengenal dirinya sendiri. Apabila seseorang mengenal dengan baik dirinya sendiri maka akan mampu melakukan keterbukaan diri dengan cermat. Kedua perempuan korban kekerasan dalam rumah tangga tidak menentukan kalimat yang tepat dalam proses melakukan keterbukaan diri mengenai kasus kekerasan yang dialaminya. Namun, terdapat satu perempuan korban yang memilih kalimat yang tepat dalam menyampaikan keterbukaan diri kepada orang tuanya. Hal ini dilakukan untuk menjaga perasaan orang tuanya setelah mengetahui cerita keterbukaan diri Informan.

Kejujuran merupakan hal yang penting dan akan mempengaruhi keterbukaan diri seseorang. Ketiga perempuan korban kekerasan dalam rumah tangga menceritakan kasus yang dialaminya tanpa menggunakan small talk sehingga langsung pada inti pembicaraan. Mereka melakukan keterbukaan diri dengan orang yang dipercaya tanpa kebohongan maupun melebih-lebihkan.

Undang-Undang Nomor 23 Tahun 2004 tentang Penghapusan Kekerasan dalam Rumah Tangga menyatakan bahwa kekerasan dalam rumah tangga adalah setiap perbuatan terhadap 
seseorang terutama perempuan, yang berakibat timbulnya kesengsaraan atau penderitaan fisik, seksual, psikologis dan atau penelantaran rumah tangga termasuk ancaman untuk melakukan perbuatan, pemaksaan atau perampasan kemerdekaan secara melawan hukum dalam lingkup rumah tangga yaitu lingkup rumah tangga adalah suami, istri dan anak, orang yang bekerja membantu rumah tangga dan menetap dalam rumah tangga tersebut. Sehingga pengaruh paling besar terhadap perempuan korban kekerasan dalam rumah tangga yang melakukan keterbukaan diri adalah timbulnya rasa takut, rasa trauma dan rasa cemas. Perasaan tersebut muncul disebabkan terror dan ancaman yang setiap hari dilakukan oleh pelaku kekerasan.

\section{Maksud dan Tujuan Keterbukaan Diri}

Maksud dan tujuan merupakan salah satu hal yang seseorang pertimbangkan melakukan keterbukaan diri. Seseorang mengungkapkan dirinya dengan tujuan tertentu. Oleh karena itu, menyadari adanya maksud dan tujuan keterbukaan diri maka seseorang akan melakukan kontrol atas keterbukaan diri pada satu sisi yang bisa dipandang sebagai salah satu bentuk kontrol agar keterbukaan diri mencapai maksud dan tujuan yang diinginkan. Tujuan perempuan korban kekerasan dalam rumah tangga selama pandemi Covid-19 melakukan keterbukaan diriadalah ingin mendapatkan perlindungan dari orang lain, keadilan dari penegak hukum dan ingin mengungkapkan rasa sakit yang selama ini dipendamnya.

Hambatan dalam melakukan keterbukaan diri adalah takut ancaman dari pelaku, mereka berada pada lingkungan yang selalu diawasi oleh pelaku, situasi pandemi Covid-19 yang mengakibatkan perempuan mengalami keterbatasan ruang gerak, alat komunikasi yang tidak dimiliki perempuan korban kekerasan sehingga sulit meminta pertolongan orang lain dan rasa ketergantungan secara ekonomi pada suami. Cara mengatasi hambatan adalah dengan mendatangi kantor kelurahan dan pulang ke rumah orang tua korban guna meminta pertolongan serta solusi dalam menyelesaikan permasalahan yang sangat menyakitkan bagi perempuan korban kekerasan dalam rumah tangga. Devito (dalam Yosal Iriantara, 2017) mengungkapkan bahwa dengan keterbukaan diri memungkinkan manusia bisa melepaskan diri dari himpitan beban psikologis. Stress maupun depresi merupakan penyakit psikologis yang membutuhkan keterbukaan diri untuk menyembuhkannya.

\section{Keakraban}

Fisher (dalam Yosal Iriantara, 2017) mengungkapkan keakraban merupakan salah satu hal yang ada kaitannya dengan komunikasi keterbukaan diri. Apa yang diungkapkan itu bisa saja hal-hal yang sifatnya pribadi atau intim misalnya mengenai perasaan kita. Membuka diri sama artinya dengan membagikan kepada orang lain perasaan kita terhadap sesuatu yang telah dikatakan atau dilakukannya atau perasaan kita terhadap kejadian yang baru saja kita saksikan. Perempuan korban kekerasan dalam rumah tangga mengungkapkan hal-hal pribadinya yaitu suaminya sering melakukan kekerasan, kekerasan yang dilakukan, berselingkuh dan mengonsumsi narkoba.

Mereka bercerita hal-hal pribadinya kepada orang yang paling dipercaya yaitu anggota PPT Seruni Kecamatan Semarang Timur. Devito (dalam Yosal Iriantara, 2017) menyatakan bahwa terdapat empat cara komunikasi antarmanusia yaitu pertukaran gaul atau kontak, kata atau bicara, pikiran atau diskusi dan hati atau kasih. Pertukaran hati atau 
kasih sebagai salah satu cara komunikasi antarpribadi hanya mungkin bisa berlangsung apabila terjadi penyingkapan diri. Tanpa ada pihak yang saling membuka diri maka pertukaran hati tidak pernah terjadi. Bahkan, bisa saja dinyatakan mustahil terjadi pertukaran hati apabila pihak-pihak yang berkomunikasi saling menutup diri, saling menjauh dan saling tidak mau tahu.

Keterbukaan diri tidak menjamin selalu dampak yang baik terhadap perempuan korban kekerasan dalam rumah tangga dalam melakukan keterbukaan diri. Peneliti menemukan beberapa masalah yang muncul setelah melakukan proses keterbukaan diri mengenai kekerasan dalam rumah tangga seperti rasa trauma, rasa kecewa dan rasa cemas. Devito (2011) menyatakan bahwa bahaya melakukan keterbukaan diri adalah penolakan pribadi atau sosial. Kita melakukan keterbukaan diri kepada orang yang kita percaya. Ketika kita ingin melakukan keterbukaan diri dengan orang yang kita anggap akanmendukung kita, hal tersebut tidak dapat menjadi jaminan. Hal tersebut bisa saja terjadi penolakan.

Kekerasan dalam rumah tangga dapat berupa kejadian tunggal atau berulang yang membentuk pola dan terjadi dalam waktu singkat atau berlanjut dalam waktu yang sangat lama. Bentuk kekerasan yang terjadi pada perempuan korban kekerasan dalam rumah tangga di Kelurahan Rejosari Kecamatan Semarang Timur Kota Semarang antara lain kekerasan fisik seperti memukul, menendang, mendorong dan lain sebagainya, kekerasan psikis seperti mendapatkan kata-kata penghinaan, dan membentak dengan keras, serta kekerasan ekonomi seperti tidak memberi nafkah pada korban dan memanfaatkan ketergantungan istri secara ekonomi untuk mengontrol kehidupannya. Hampir setiap hari mereka mendapatkan ancaman dari suami berupa pembunuhan dan mengancam akan membawa anaknya pergi.

\section{Analisis Kebutuhan dan Sumber}

Hasil penelitian yang dilakukan terhadap perempuan korban kekerasan dalam rumah tangga selama pandemic Covid-19 di Kelurahan Rejosari Kecamatan Semarang Timur Kota Semarang adalah perempuan korban kekerasan dalam rumah tangga telah melakukan keterbukaan diri dengan baik Namun, peneliti menemukan beberapa masalah yang muncul setelah mereka melakukan proses keterbukaan diri mengenai tindak kekerasan seperti munculnya rasa trauma dan rasa cemas.Untuk memecahkan permasalahan yang dialami, peneliti melakukan analisis kebutuhan perempuan korban kekerasan yaitu mengurangi rasa trauma perempuan dan anak korban kekerasan dalam rumah tangga melalui Lembaga Layanan Rujukan Rumah Aman dan mengurangi perasaan cemas perempuan korban kekerasan dalam rumah tangga melalui Lembaga Layanan Rujukan Rumah Aman.

Kasus kekerasan dalam rumah tangga sebagian besar masyarakat hanya melihat dan fokus terhadap pelaku kekerasan seperti hukuman yang akan didapatkan sesuai dengan perbuatan pelaku. Mereka, tidak melihat kondisi korban yang mengalami trauma dan cemas. Permasalahan ini tentunya harus dicari alternatif solusi agar perempuan dan anak korban kekerasan dapat hidup dengan tenang dan menjalani kehidupan dengan semestinya.

Upaya pemecahan masalah adalah dengan memanfaatkan sistem sumber untuk memenuhi kebutuhan perempuan korban kekerasan dalam rumah tangga di Kelurahan Rejosari Kecamatan Semarang Timur Kota 
Semarang. Sistem sumber tersebut yaitu sistem sumber formal yang dapat memberikan pelayanan secara langsung seperti Dinas Pemberdayaan dan Perlindungan Anak Kota Semarang dan Dinas Sosial Kota Semarang. Kemudian, sistem sumber informal yang dapat memberikan dukungan emosional terhadap korban kekerasan adalah keluarga. Sistem sumber selanjutnya adalah sistem sumber kemasyarakatan. Sistem sumber kemasyarakatan dalam penelitian ini yaitu kepolisian, rumah sakit, sekolah, Rumah Aman dan LRC-KJHAM Kota Semarang.

Allen Pincus dan Anne Minahan (1973) mengungkapkan bahwa sumber adalah segala sesuatu yang memiliki nilai, sesuatu yang berada dalam simpanan atau telah tersedia, dimana orang dapat menggali dan menggunakannya sebagai alat sehingga berfungsi untuk memenuhi kebutuhan atau memecahkan masalah yang dihadapi perempuan korban kekerasan dalam rumah tangga selama pandemi Covid-19 di Kelurahan Rejosari Kecamatan Semarang Timur Kota Semarang.

\section{KESIMPULAN}

Hasil penelitian menunjukkan keterbukaan diri perempuan korban kekerasan dalam rumah tangga selama pandemi Covid-19 telah dilakukan dengan baik. Pasca melakukan keterbukaan diri terdapat permasalahan yang muncul yaitu rasa trauma dan rasa cemas terhadap tindak kekerasan dalam rumah tangga. Berdasarkan hasil penelitian tersebut, maka peneliti mengusulkan program pendampingan sosial terhadap rasa trauma dan rasa cemas perempuan korban kekerasan dalam rumah tangga selama pandemi Covid-19 pasca melakukan keterbukaan diri melalui
Lembaga Layanan Rujukan Rumah Aman. Program ini bertujuan untukmemberikan rasa aman, mengurangi rasa trauma dan rasa cemas perempuan korban kekerasan dalam rumah tangga selama pandemi Covid-19 pasca melakukan keterbukaan diri.

Pelaksanaan program ini memerlukan komitmen dan keterlibatan secara aktif dari tiga perempuan korban kekerasan dalam rumah tangga. Pelaksanaan program melalui beberapa kegiatan tersebut didukung oleh sumbersumber yang dapat dimanfaatkan seperti sarana dan prasarana yang telah disediakan. Kemudian, usulan program yang diberikan berdasarkan analisis SWOT diketahui bahwa kekuatan dan peluang lebih besar dibandingkan dengan kelemahan dan ancamannya. Hal tersebut mengartikan bahwa usulan program ini layak untuk dilaksanakan. Sehingga, program yang telah dicanangkan mampu menjadi pemecah masalah dari perempuan korban kekerasan dalam rumah tangga di Kelurahan Rejosari Kecamatan Semarang Timur Kota Semarang agar mampu berfungsi sosial kembali tanpa diliputi rasa trauma dan rasa cemas.

\section{DAFTAR PUSTAKA}

Adi Fahrudin. 2012. Pengantar Kesejahteraan Sosial. Bandung: Refika Aditama

Agus Sutiyono. 2010. Dahsyatnya Hypnoparenting. Jakarta: Penebar Plus

Altman \& all. 1973. Social Penetration: The Development of Interpersonal Relationships. New York: Rinhart \& Winston

Anung, dkk. 2020. Pengaruh Kebijakan Social Distancing pada Wabah Covid-19 terhadap Kelompok Rentang di Indonesia. Jurnal Kebijakan Kesehatan Indonesia

Budi Wibhawa, dkk. 2010. Dasar-Dasar Pekerja Sosial. Bandung: Widya Padjadjaran 
Derlega. 1993. Self Disclosure. London: Sage Publication

Dinas Pemberdayaan Perempuan dan Perlindungan Anak Kota Semarang. 2020. Data Kekerasan Terhadap Perempuan. Retrived 17 August 2020 from

http://103.101.52.46/?dari_tanggal $=0$ 1-01-2020\&sampai_tanggal $=28-07-$ 2020\&kecamatan $=\&$ lokasi_korban $=1$ \&lokasi_pelaku=1

Dwi Heru Sukoco. 2011. Praktek Pekerjaan Sosial dan Proses Pertolongannya. Bandung: Koperasi Mahasiswa STKS Bandung

Edi Suharto. 2006. Membangun Masyarakat Memberdayakan Rakyat. Bandung: Refika Aditama

Keputusan Gubernur Jawa Tengah Nomor 360/3 Tahun 2020 tentang Tanggap Darurat Bencana Covid-19

Komnas Perempuan. 2020. Data Catatan Tahunan 2020. Retrived August 16 2020

fromhttps://www.komnasperempuan. go.id/reads-infografis-bentukkekerasan-terhadap-perempuan-fisikpsikis-seksual-dan-ekonomi-catahu$\underline{2020}$

Kompas. 2021. Hari ini dalam Sejarah: WHO Tetapkan Covid-19 Sebagai Masalah Global. Retrived May 26 2021 from https://www.kompas.com/tren/read/2 021/03/11/104000165/hari-ini-dalamsejarah--who-tetapkan-covid-19sebagai-pandemi-global?page $=$ all

Mariam B, Gainau. 2009. Keterbukaan Diri (Self Disclosure) Siswa dalam Perspektif Budaya dan Implikasinya bagi Konseling. Jurnal Ilmiah Universitas Katolik Widya Warta, 33(1), 1-18

Masturah. 2013. Pengungkapan Diri antara Remaja Jawa dan Madura. Jurnal Online Psikologi Universitas Muhammadiyah Malang
Messing, J.T. 2014. Intimate Partner Violence And Abuse. Encyclopedia of Social Work. NASW and Oxford University Press

Moerti Hadiati Soeroso. 2012. Kekerasan Dalam Rumah Tangga. Jakarta: Sinar Grafika

Moleong, Lexy J. 2017. Metodologi Penelitian Kualitatif Edisi Revisi. Bandung: PT Remaja Rosdakarya

Pincus, Allen and Anne Minahan. 1973. Social Work Practice: Model AndMethode. Madison: F.E Peacock Publisher, Inc

Portal Informasi Indonesia. 2020. Tiga Jurus Darurat Melawan Pandemi Covid-19. Retrived 17 August 2020 from https://www.indonesia.go.id/narasi/indo nesia-dalam-angka/ekonomi/tiga-jurusdarurat-melawan-pandemi-covid-19

Sugiyono. 2017. Metodelogi Penelitian Kualitatif Edisi Ke-3. Bandung: Alfabeta

Supratiknya. 1995. Tinjauan Psikologis Komunikasi Antar Pribadi. Yogyakarta: Kanisius

Susilowati, E., \& Azzasyofia, M. (2020). The parents stress level in facing children study from home in the early of covid19 pandemic in Indonesia. International journal of science and society, 2(3), 1-12.

Theresia Vania, dkk. 2020. Dampak Pandemi Covid-19 Terhadap Kekerasan Dalam Rumah Tangga. Jurnal Online Kesejahteraan Sosial Universitas Padjajaran

Undang-Undang Nomor 1 Tahun 1974 tentang Perkawinan

Undang-Undang Nomor 23 Tahun 2004 tentang Penghapusan Kekerasan Dalam Rumah Tangga

Undang-Undang Nomor 39 Tahun 1999 tentang Hak Asasi Manusia

Undang-Undang Republik Indonesia Nomor 2 Tahun 2020 tentang Penetapan Peraturan Pemerintah Pengganti Undang-Undang Nomor 1 Tahun 2020 tentang Kebijakan Keuangan Negara dan Stabilitas Sistem 
Keuangan untukPenanganan Pandemi Corona Virus Disease 2019 (Covid-

19) dan/atau Dalam Rangka Menghadapi Ancaman yang Membahayakan Perekonomian Nasional dan/atau Stabilitas Sistem Keuangan Menjadi Undang-Undang Yosal Iriantara. 2017. Komunikasi Antarpribadi. Tangerang: Universitas Terbuka

Zastow, Charles. 2017. Introduction to Social Work and Social Welfare: Empowering People (Twelfth Edition). USA: Cengage Learning 